\title{
El control estatal a la docencia en los primeros gobiernos peronistas*
}

Marina Kabat ${ }^{* *}$

Artículo de investigación sobre el control a la docencia, las restricciones a la libertad de enseñanza, condiciones de empleo docente y respuesta sindical bajo los dos primeros gobiernos peronistas en la Argentina.

Recibido: 13 de abril de 2020

Evaluado: 5 de noviembre de 2020

Aceptado: 14 de diciembre de 2020

Publicado: 1 de julio de 2021

Citar como:

Kabat, M. (2021). El control estatal a la docencia en los primeros gobiernos peronistas. Hallazgos, 18(36), 53-101. https://doi.org/10.15332/2422409X.5657

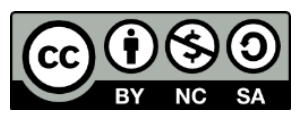

\section{Resumen}

A mediados del siglo XX en la Argentina el peronismo recurrió a la educación como medio de propaganda política. Esto requirió un fuerte control estatal sobre la docencia. Con base en documentos oficiales recientemente desclasificados se analizan los mecanismos desplegados por el Estado peronista para obtener información sobre los docentes, detectar y despedir a aquellos que no comulgaban con la ideología oficial.

\footnotetext{
* Artículo de investigación científica y desarrollo tecnológico.

** Doctora en Historia. Investigadora independiente del Conicet.

Correo electrónico: marinakabat@yahoo.com.ar

ORCID: https://orcid.org/0000-0001-7662-4643
} 
En complemento con esto, a partir de documentos sindicales se examina la respuesta de uno de los principales gremios docentes del periodo. La información relevada permite cuestionar estudios anteriores que afirmaban que los despidos docentes habían seguido los canales institucionales correspondientes, que las denuncias eran formuladas de forma espontánea por sectores populares carentes de otros canales para hacer oír su voz. Por el contrario, en el control a los docentes son actores fundamentales tanto la Policía como los servicios especiales de información, y gran parte de los despidos a docentes fueron ejecutados por fuera de los procedimientos institucionales del sistema educativo, en ausencia de los sumarios previstos por este. El estudio de tales casos permite reflexionar sobre los alcances de la política represiva de los primeros gobiernos peronistas y sobre la articulación de los mecanismos consensuales y coercitivos en la construcción de hegemonía.

Palabras clave: Educación; Administración de la educación; Condiciones de empleo del docente; Docencia; Libertad de enseñanza; Sindicato de profesores.

\section{State control of teaching during the first Peronist governments}

\section{Abstract}

In the mid-twentieth century in Argentina, Peronism resorted to education as a means of political propaganda. This required a strong state control over teaching. Based on recently declassified official documents, this article analyzes the mechanisms deployed by the Peronist State to obtain information about teachers, and to detect and dismiss those who did not agree with the official ideology. In addition, the response of one of the main teachers' unions of the period is examined based on union documents. The information gathered allows us to question previous studies that affirmed that teacher dismissals had followed the corresponding institutional channels, that complaints were spontaneously made by the working class lacking other channels to make 
their voices heard. On the contrary, both the Police and the special information services were key factors in the control of teachers, and most teachers were fired disregarding the institutional procedures of the educational system. The study of these cases allows us to ponder on the scope of the repressive policy of the first Peronist governments and on the articulation of consensual and coercive mechanisms in the construction of hegemony.

Keywords: Education; Education administration; Teachers' employment conditions; Teaching; Teaching freedom; Teachers' unions.

\section{Controle estatal da docência nos primeiros governos peronistas}

\section{Resumo}

Em meados do século XX, na Argentina, o peronismo recorreu à educação como meio de propaganda política. Isso exigia um forte controle do Estado sobre o ensino. Com base em documentos oficiais recentemente divulgados, são analisados os mecanismos implantados pelo Estado peronista para obter informações sobre os docentes, detectar e demitir aqueles que não concordavam com a ideologia oficial. Além disso, com base em documentos sindicais, analisa-se a resposta de um dos principais grêmios docentes do período. A informação obtida permite questionar estudos anteriores que afirmaram que a demissão de professores obedeceu aos canais institucionais correspondentes, que as denúncias eram formuladas de forma espontânea por setores populares que careciam de outros canais para fazer ouvir a sua voz. Pelo contrário, no controle dos docentes, tanto a Polícia como os serviços de informação especial são atores fundamentais, sendo que grande parte das demissões de docentes foram efetuadas fora dos procedimentos institucionais do sistema educativo, inclusive com a ausência dos sumários que ele previa para isso. $\mathrm{O}$ estudo de tais casos permite refletir sobre o alcance da política repressiva dos primeiros governos peronistas e sobre a 
articulação de mecanismos consensuais e coercitivos na construção da hegemonia.

Palavras-chave: Educação; Administração da educação; Condições de emprego do docente; Docência; Liberdade de ensino; Sindicato de professores.

\section{Introducción}

$\mathrm{El}$ ascenso del peronismo al poder en la Argentina estuvo asociado a fuertes transformaciones y conflictos en el ámbito educativo. Durante el gobierno militar que antecede las presidencias democráticas de Perón (1943-1946), periodo en el cual Perón llega a ser el hombre fuerte del Gobierno al acumular en forma progresiva los cargos de secretario de Trabajo y Previsión, ministro de Guerra y vicepresidente de la nación, se restablece la educación religiosa en las escuelas públicas, se intervienen universidades y se despiden docentes que se oponían a estos nuevos lineamientos. El Grupo de Oficiales Unidos (GOU), la logia militar a la que pertenecía Perón, es uno de los sectores dentro del Gobierno que impulsa esa política.

Durante sus presidencias, Perón mantiene los principales rasgos de esta política educativa y, en particular, en su segundo mandato tiende a profundizarla. En la nueva etapa que se abre en 1952, el peronismo recurrió a la educación como medio de propaganda política. Con tal objeto se publican nuevos manuales escolares y el Gobierno amplía su control sobre la docencia. Este se ejerce a través de mecanismos punitivos como traslados y otras sanciones, y especialmente mediante la separación de sus cargos a los docentes opositores.

En este artículo, con base en documentos oficiales recientemente desclasificados, se analizan los mecanismos desplegados por el Estado peronista para obtener información sobre los docentes y detectar y 
despedir a aquellos que no comulgaban con la ideología oficial. En complemento con esto, teniendo en cuenta documentos sindicales se examina la respuesta de uno de los principales gremios docentes del periodo: la Agremiación del Docente Argentino (ADA), creada en 1950 bajo estímulo estatal con el propósito de concentrar el conjunto de los docentes. La ADA fue posteriormente intervenida por la Confederación General de Trabajadores (CGT), y se disolvió. Sobre sus bases se creó una nueva organización, la Unión de Docentes Argentinos (UDA). Esta, en vez de integrarse a la CGT, lo hizo a la Confederación General de Profesionales (CGP), entidad creada a fines del gobierno peronista, con la intención de contrarrestar en parte la influencia de la CGT, de cuya órbita se substraían algunos gremios. Ni la ADA primero ni la UDA después lograron reunir el conjunto de los docentes, pese a ser, cada una a su tiempo, la entidad profesional que gozaba de reconocimiento oficial. Este reconocimiento es lo que habilita a la entidad a interceder ante el Gobierno en casos de despidos injustificados.

Para la presente investigación se ha trabajado con dos importantes fondos documentales, ambos pertenecientes al Archivo General de la Nación (AGN) de Argentina, Archivo Intermedio. Por un lado, se relevó información del Fondo Documental Ministerio del Interior, expedientes secretos, confidenciales y reservados. Se trata de documentos pertenecientes al Ministerio del Interior que en el periodo contemporáneo han sido desclasificados. La mayoría de los documentos citados de este fondo documental corresponden a informes u otras formas de comunicación entre diferentes reparticiones policiales y el Ministerio del Interior.

El segundo fondo documental que se examinó fue el Fondo Nacional de Recuperación Patrimonial (FNRP). Tras el derrocamiento de Perón, en 1955, el gobierno militar decidió investigar los supuestos delitos del 
gobierno peronista, para lo cual crea la Comisión Nacional de Investigaciones. Esta comisión tenía amplias atribuciones, incluso inconstitucionales, para realizar sus procedimientos; podía investigar reparticiones públicas o individuos ligados al Gobierno, e incautar documentación pública y privada. La comisión creó subcomisiones dedicadas a indagar distintos ministerios o funcionarios. En 1956 se creó la Fiscalía Nacional de Recuperación Patrimonial para ampliar las indagaciones de su predecesora, actividad que continuó hasta 1958. La Fiscalía, además, se constituye en la depositaria del material producido hasta entonces por la comisión (testimonios obtenidos y documentación incautada).

En 1967 se dan por finalizadas las funciones de la FNRP y las actuaciones pasan a la Secretaría General de la Presidencia, y luego, al Ministerio de Justicia. Recién en 2002 esta documentación pasó a ser custodiada por el Archivo General de la Nación, y se inician las tareas para que los investigadores puedan consultar el fondo documental. Mucha de la documentación de los gobiernos peronistas que se creía perdida o destruida está reunida allí. Archivos completos de diversos ministerios y secretarías se han conservado por esta vía. En el caso del presente artículo, se analizó material de dos de las subcomisiones de la FNRP: la subcomisión 20, correspondiente al Ministerio de Educación, y la subcomisión 31, "Ex Secretaría de Asuntos Técnicos y Presidencia de la Nación”, repartición estatal que tenía incidencia sobre el empleo público. En particular, el material conservado en la subcomisión 20 resultó de especial interés para esta indagación. Por una parte, conserva material perteneciente al Ministerio de Educación, incluso documentos secretos que son objeto de análisis de este trabajo. Por otra parte, esta subcomisión también preservó documentos originales incautados a la UDA. De este modo, se ha podido acceder a libros de actas, boletines sindicales y diverso 
material de propaganda gremial. Como parte de su indagación, la subcomisión tomó testimonio a diversos activistas sindicales del periodo peronista, y guardó registro escrito. Se ha trabajado con estos testimonios con el recaudo de saber que estos son recabados en forma posterior a los hechos que se relatan y en un contexto represivo. Por eso mismo se procede a cotejar la información de esta fuente oral con los documentos escritos producidos por el sindicato en forma contemporánea al proceso histórico estudiado. En todos los casos se halló una correspondencia entre estos. Cabe señalar que la misma coherencia ha sido constatada entre los documentos de los dos fondos documentales examinados.

El estudio empírico realizado permite reflexionar sobre los alcances de la política represiva de los primeros gobiernos peronistas y sobre la articulación de los mecanismos consensuales y coercitivos en la construcción de hegemonía. En sintonía con los escritos de Anderson (1981) y Sartelli (1996), se considera la hegemonía como la expresión que asume la dominación de una clase social sobre otra en aquellos momentos en que esta no enfrenta desafíos abiertos, por los que puede presentarse bajo formas consensuales. La hegemonía es una combinación de coerción y consenso, y se asienta en última instancia en el uso o la amenaza de uso de medios coercitivos.

A su vez, el consenso mismo no es fruto de opciones completamente autónomas y libres. Lo que las personas pueden aceptar o no en un periodo histórico dado no es el fruto exclusivo de su libre elección. Cada decisión debe tomarse en un momento histórico concreto. Por ello, los conflictos sociales previos y sus resultados plasmados en las relaciones de fuerza entre las clases sociales inciden en lo que una clase dominada pueda aceptar en cierto momento histórico. Al mismo tiempo, por esa razón, el consenso acordado no es una potestad permanente. Por el contrario, el cambio de las relaciones de fuerza entre clases modifica los límites de lo 
aceptable. Esto puede darse mediante una confrontación radical en torno al consenso previo o, más comúnmente, mediante relecturas o resignificaciones de aquello que se había acordado.

En consonancia con esta perspectiva teórica, no se presenta aquí una visión dicotómica y esencialista de la docencia confinada en dos polos: peronismo y antiperonismo. Por el contrario, esta investigación muestra la modificación de posiciones políticas a lo largo del periodo histórico estudiado. Más allá de que estas transformaciones impliquen o no una redefinición de la adscripción partidaria de los docentes, lo que las fuentes sindicales indican es el desarrollo de una batalla por redefinir el marco de lo que se considera una injerencia legítima del Estado en el ámbito educativo.

\section{Estado de la cuestión: educación, sindicatos y peronismo}

Hay cierto consenso bibliográfico respecto de que el peronismo, a diferencia de lo que ocurre en otros sectores, no constituyó una fuerza hegemónica dentro del colectivo docente. Algunos autores atribuyen esto al origen de clase de este grupo de asalariados, a quienes consideran más cercanos a la pequeña burguesía (Perazza y Legarralde, 2007; Vázquez, 2005; Alliaud, 1993). Otros autores señalan también el rechazo a la política educativa del Gobierno y la insatisfacción en cuanto a la situación laboral, como otras causas de este posicionamiento (Puiggrós y Bernetti, 1993). Otros elementos negativos que pudieron haber desempeñado un papel destacado fueron la persecución de dirigentes por parte del Gobierno (Nigro, 1984), el requisito de afiliación partidaria o de la Jura de la constitución peronista de 1949 (Puiggrós y Bernetti, 1993; Kabat, 2017) o la incidencia del Partido Peronista Femenino en la educación, sea a través de denuncias o de obtención de cargos por mediación de aquel (Kabat, 
2017). Gran parte del personal dirigente de dicho partido eran maestras (Barry, 2009), lo que puede haber favorecido esta intromisión.

En cuanto a la insatisfacción laboral de los docentes, por un lado, hay que considerar que, junto a otros trabajadores estatales, efectivamente pertenecen a los colectivos laborales menos beneficiados por el peronismo (Newland y Cuesta, 2017; Moyano Llerena, 1957; De Luca y D’Auria, 2017). Si se observa su evolución salarial, es evidente que los primeros gobiernos peronistas pueden enmarcarse en lo que Romina De Luca define como un segundo periodo en la evolución salarial docente, signado por la caída del salario real docente, en contraposición con la etapa anterior, en la cual los salarios reales de los docentes habían ido aumentando hasta alcanzar su tope en 1930 (De Luca y D’Auria, 2017, pp. 196 y 197).

Por otro lado, demandas laborales elementales como estabilidad en el puesto y mecanismos claros tanto de ingreso a la docencia como de selección del personal para ascensos no estaban garantizados. En estos últimos puntos, la cuestión laboral se confunde con el asunto institucional: nombramientos y ascensos eran aspectos que afectaban a los docentes como trabajadores, pero que, al mismo tiempo, estaban asociados al funcionamiento general del sistema educativo. En ese sentido, en ocasiones, las demandas colectivas de los docentes entremezclan reclamos laborales con requerimientos en torno al mejor y más eficiente funcionamiento del sistema educativo.

De este modo, podría decirse que la injerencia del peronismo en el sistema educativo iba en contra de lo que Ascolani (1999) definió como el "legalismo" de las asociaciones profesionales tradicionales dentro del mundo docente. Según este autor, el núcleo de este legalismo de los sindicatos docentes era la defensa de la autonomía relativa del mundo educativo. Pero, al mismo tiempo, este legalismo actuaba como un mecanismo de defensa de derechos laborales. Es significativo que uno de 
los puntos centrales de conflicto de los gremios docentes con el peronismo, según Nardacchione (2014), sea el mismo Estatuto Docente de 1954. Pese a algunos avances planteados por dicho estatuto en torno a la carrera docente, este habría generado rechazo porque supeditaba el goce de derechos sindicales a la adhesión política al régimen por parte de los docentes (Nardacchione, 2014).

Como señala Gindin (2008), la preocupación y los reclamos referentes a los estatutos expresan la demanda por la estabilidad laboral, e implican una resistencia frente al control total y discrecional del Estado sobre el empleo. En la provincia de Buenos Aires, Pettiti (2017) ha estudiado los intentos de modificación de la Ley 4695 de escalafón y estabilidad del magisterio, que desde 1938 fijaba la obligación de la realización de un sumario previo al despido, aunque la ley no se cumplía. La autora reseña los conflictos que se suscitaron ante esta tentativa. El promotor de esta fue Alejandro Greca, a cargo de la Dirección General de Escuelas, quien en 1946 propuso suspender el escalafón hasta tener una nueva norma. Los docentes bloquearon su iniciativa.

Como muestra Pettiti, para lograr esto los docentes contaron con el apoyo en el ámbito legislativo de los representantes laboristas que integraban el peronismo. Estos también se oponían a las exoneraciones que, en tres meses de gestión peronista, ascendían a 220, pues defendían la estabilidad de los empleados estatales. La Unión Argentina de Maestros, una federación creada en 1943, se manifestó en su primer Congreso, realizado en diciembre de 1946, por la educación laica y contra las exoneraciones que habían afectado a muchos de sus afiliados (Pettiti, 2017, pp. 209-210). El conflicto en torno al intento de modificar el escalafón tuvo amplia repercusión en la prensa (Pettiti, 2013), lo que puede haber contribuido a una solución favorable para los docentes. Pettiti reseña la evolución posterior de la normativa. Si bien no se encuentra exenta de conflictos, 
estos no alcanzan la misma repercusión de aquel 1946, cuando los docentes consiguieron la remoción del proyecto de Greca y su propio remplazo al mando de la Dirección General de Escuelas.

En ese sentido, el proceso que Pettiti reconstruye puede entenderse mejor si se contextualiza en el marco histórico más amplio. No es extraño el nivel de conflictividad presente en 1946 en la provincia de Buenos Aires, donde el laborismo es fuerte y todavía busca incidir en las decisiones de un gobierno al cual aún pertenece. Sin embargo, en años posteriores, cuando esta oposición interna dentro del peronismo es eliminada, el margen de maniobra de los diferentes colectivos obreros se reduce (Torre, 2014; Doyon, 2006, pp. 293-305). La censura de la prensa opositora o peronista disidente - que resulta más severa desde 1949- también contribuye a restringir el margen de maniobra sindical (Kabat, 2017).

Según varios autores, el control político sobre la docencia se intensifica desde 1952. A este respecto, Plotkin (1995) señala la edición de los denominados manuales peronistas a partir de esa fecha. Camarota, por su parte, examina el Boletín de Comunicaciones del Ministerio de Educación, directivas publicadas en mayo de 1952 que instaban a la persecución y la censura. Cammarota (2010) califica dicha directiva como la más audaz que había impartido el Gobierno. En cuanto a la provincia de Buenos Aires, Pettiti (2017) aporta evidencia en el mismo sentido al señalar que, bajo el Gobierno de Aloé (1952-1955), empeoró la situación de los docentes sumariados porque el sumario pasó a ser secreto y, durante el proceso, antes de que hubiera una resolución, los docentes afectados dejaban de percibir su salario por hasta noventa días. Sin embargo, la autora no analiza este dato como parte de un proceso más amplio de transformación en el ámbito educativo. Por el contrario, su interpretación se aproxima más a la mirada de Fiorucci, quien establece una línea de continuidad durante las dos primeras presidencias de Perón y con quien está de 
acuerdo en otros puntos. Fiorucci cuestiona a quienes observan un quiebre o una profundización de las tensiones a partir de 1952, momento en el que se interpela al cuerpo docente a la difusión de la doctrina nacional, luego de la sanción del Segundo Plan Quinquenal. Cabe señalar que Fiorucci también relativiza la idea de la existencia de un colectivo docente homogéneo que fuera en su conjunto aliado u opositor al Gobierno (Fiorucci, 2012a, 2012b y 2013).

Una posición semejante, que busca distanciarse al mismo tiempo de lecturas más apologéticas como las de Puiggros y de las más críticas como las de Plotkin, tiene Somoza (2006), quien considera que algunos autores sobredimensionan en términos relativos el peso del componente ideológico del peronismo al subvalorar la presencia de este mismo elemento a lo largo de toda la historia del sistema educativo. En este aspecto, Pettiti concuerda con Firorucci en torno a su rechazo a una supuesta visión dicotómica del magisterio que presentaría a los docentes o bien como agentes pasivos cooptados por el Gobierno o como acérrimos opositores. A juicio de Pettiti (2017), esas miradas dejan poco espacio a la diversidad de experiencias gremiales. Por su parte, una investigación sobre cuadernos escolares parece indicar un margen de libertad de los docentes para desarrollar los contenidos que el peronismo les planteaba (Gvirtz, 2005).

En el marco de tales debates, este artículo retoma el interrogante alrededor de la existencia o no de un quiebre de la política educativa peronista en torno a 1952 y su eventual impacto sobre la relación de la docencia con el peronismo. Aquí se sostiene la hipótesis de que, efectivamente, hay un cambio en la política educativa del peronismo en torno a 1952 y que este giro es, incluso, más marcado de lo que hasta ahora consideraban los autores que defendían esta tesis. Este cambio más drástico está dado no solo por el direccionamiento más agudo de las 
políticas educativas y manuales escolares hacia la exaltación del régimen político vigente, sino también -y este es precisamente uno de los datos nuevos que se aportan en la presente indagación - a partir de la configuración de una estructura específica de vigilancia a la docencia. En este sentido, la evidencia que se halló respecto a los despidos docentes durante el primer peronismo se contrapone a la imagen esbozada por Fiorucci (2012a, 2012b y 2013). Esta autora escribe sobre los sumarios que el Consejo Nacional de Educación hizo a los docentes en la época peronista, muchos de los cuales terminaron en despido. Fiorucci señala que eran frecuentes las denuncias contra los docentes antiperonistas. Estas denuncias provendrían de todo tipo de actores (docentes de nivel inferior o superior a aquellos denunciados, padres o miembros de la comunidad), aunque predominarían las denuncias entre actores signados por relaciones horizontales entre sí. Fiorucci considera que estas denuncias son espontáneas y que no pueden ser entendidas -al menos no exclusivamente- como un síntoma de dominación política. Por el contrario, las interpreta como una forma de ejercer la voz de sectores débiles o carentes de poder a quienes el peronismo habría investido de nuevas potestades como demandar o informar al Estado.

Para Fiorucci, las denuncias enfrentan a trabajadores y vecinos entre sí y dan cuenta de una vigilancia omnipresente que proviene desde abajo y se ejerce en forma horizontal. Esa vigilancia constituiría una forma de participar y asumir la identidad peronista. A su vez:

La preeminencia de esa vigilancia difusa explicaría algunos de los mitos que circulan en el imaginario público sobre el control que pesaba sobre la sociedad en esos años. Esta produce una atmósfera asfixiante que genera temor e inseguridad porque no se pueden aislar e identificar los mecanismos de control y censura. (Fiorucci, 2013, p. 21) 
En torno a la confección y resolución de los sumarios a los que estas denuncias dieron lugar, Fiorucci señala un correcto desarrollo de estos -al menos como norma general-, cierto celo por la comprobación de la veracidad o no de las denuncias, y la desestimación de las que fueran falsas. Finalmente, recalca que la resolución final de cada caso quedaría en manos de los inspectores, quienes tendrían en cuenta al dictaminar el concepto que el docente tiene en la comunidad escolar. En ese sentido, todo el procedimiento se desarrollaría dentro del ámbito educativo:

Hay un mito de que el peronismo siempre castigó a los desafectos, ¿no? Que en el peronismo, aquellos que no se ajustaban a la normativa serían castigados. Lo que yo descubrí al desandar los sumarios es que la suerte de estas personas denunciadas dependía casi exclusivamente de lo que decía el inspector. Así que los inspectores asumen el rol de árbitros morales y legales y mediadores del conflicto que inunda a la comunidad escolar. No es su rol difundir el mensaje político sino todo lo contrario, mediar en los conflictos que provoca la difusión de este mensaje político. Y lo que se puede ver es que revelan cierta aprensión por este problema que surge y frente a la difusión del uso de la práctica de la denuncia y que son muy cuidadosos a la hora de establecer sanciones. En gran medida lo que determina la suerte de la persona acusada es la evaluación de su capital social. O sea, el sumario convoca voces: se entrevistaba al policía, a los padres, al portero, a todos, y si la persona era querida en su medio no era sancionada aun cuando se supiera que militaba en el partido radical o en el partido comunista. (Fiorucci, 2012b, p. 10)

En ese sentido, Fiorucci (2012a) resalta que el peronismo "respetó los procedimientos institucionales y evitó particularmente castigar a miembros de la comunidad escolar que gozaran de reputación en su medio" (p. 147). Fiorucci construye su interpretación de acuerdo con una muestra de sumarios iniciados a partir de denuncias formuladas ante el Consejo Nacional de Educación. También la configura con base en una 
muestra aleatoria de legajos del nivel primario del sistema educativo del Consejo Nacional de Educación. Ella releva tres metros lineales de legajos por cada año de gobierno peronista, a excepción de 1949, 1950 y 1953, en los cuales la magnitud de documentación disponible era inferior (Fiorucci, 2013, p. 5). Sin embargo, no indica la cantidad de metros lineales totales que ocupan los legajos correspondientes al periodo que ella estudió. Por lo cual, no es posible conocer el grado de representatividad de la muestra con la que ha trabajado. Sí se sabe que dentro de su muestra ha encontrado 50 sumarios a docentes por mal desempeño en sus funciones, de los cuales 25 traían a colación el tema del antiperonismo (Fiorucci, 2013, p. 6).

Por otra parte, la fuente que Fiorucci emplea solo considera una porción de los despidos docentes del periodo: aquellos que se tramitaron en primera instancia en el Consejo Nacional de Educación, sin incumbencia de otras esferas del Gobierno, y que se procesaron a través de sumarios formales. Sin embargo, durante el periodo, muchos docentes llegaron a ser despedidos por otros canales. Los despidos ejecutados en ausencia de sumarios son lo suficientemente importantes para que, como veremos más adelante, el sindicato docente UDA de propia filiación peronista reclame contra ellos. Estos casos muestran procesos y vías de resolución muy diferentes a los que describe Fiorucci, ya que intervienen servicios de inteligencia y organismos como el Ministerio de Asuntos Políticos destinados a monitorear la actividad política de los ciudadanos.

\section{Los docentes en la mira de los servicios de inteligencia}

El control sobre miembros del magisterio se intensifica desde 1952, pero tiene antecedentes que se remontan a la etapa de los orígenes del peronismo bajo el gobierno militar de 1943 a 1945. Entre los documentos secretos, confidenciales y reservados del Ministerio del Interior, recientemente desclasificados, se hallaron varios archivos vinculados al 
trabajo de inteligencia sobre miembros del magisterio. Tras el golpe militar de 1943, el comandante de Gendarmería, Miguel Ángel Cristobo, fue designado comisionado investigador del Ministerio del Interior. Su misión consistía en detectar la influencia del comunismo en el país. Para ello solicita una serie de informes a los interventores de las distintas provincias. Dentro de estos pide información en específico sobre el personal del área educativa: "Interesa conocer especialmente a esta Instrucción, nombres, domicilios y otros antecedentes de personas con cargos docentes que presten servicios en establecimientos educativos en esa Provincia, cuya conducta y actividades las identifiquen con ideologías de carácter comunistas o extrema izquierda" (Comisionado investigador del Ministerio del Interior, 1944, párr. 1).

En esta etapa, y asociado también al avance de la Iglesia en el mundo educativo, se producirán numerosos despidos. Figuras asociadas a la Iglesia alcanzan posiciones de poder dentro del sistema educativo $\mathrm{y}$, tras obtener la reimplantación de la enseñanza religiosa en las escuelas públicas, bregan por una mayor cristianización de las escuelas mediante el despido de docentes ateos, socialistas, judíos y liberales (Zanatta, 2013). Esta primera oleada de despidos crea una importante oposición popular. Por ejemplo, en Entre Ríos, cuyas colonias judías habían sido especialmente afectadas por estos despidos, hubo una fuerte respuesta comunitaria (Leyes, 2017). Esta oposición logró que muchos despidos se revirtieran. En abril de 1945, en la ciudad de Rosario se realizó un acto de homenaje a los maestros reincorporados. A este asistieron 2000 personas, según el informe de la Policía al Ministro del Interior (Policía de la Provincia de Santa Fe, 1945, párr. 1), entre ellas Juan Ingalinella, médico afiliado al Partido Comunista, que sería torturado y desaparecido durante la segunda presidencia de Perón. 
El problema del control a los docentes como sector específico reaparece con fuerza en 1952. Ese año, servicios policiales de diferentes provincias realizaron informes sobre docentes desafectos al Gobierno, que fueron elevados al Ministerio del Interior. Todos estos documentos revestían en su momento carácter secreto.

Un expediente secreto del Ministerio del Interior contiene varios documentos de inteligencia sobre docentes de Río Negro que renunciaron a su afiliación al Partido Peronista (Franco y Amaro, 1952a, foja 1; Franco y Amaro, 1952b, foja 2; Franco y Amaro, 1952c, foja 3). Otro expediente de la misma provincia muestra el espionaje a tres maestras. Una es suplente de la Escuela Nacional n. ${ }^{0}$ 42. Se la vio asistir a actos organizados por radicalismo. No asistió, en cambio, a los del Partido Peronista; pertenece a familia radical, y no está afiliada al peronismo. Se señala como dato ilustrativo que en el Día de la Bandera presenció los festejos, pero se retiró del acto en el mismo momento en que un orador elogiaba la política de transporte del Gobierno (López, 1952a, foja 1).

De una maestra de la escuela $n .{ }^{\circ} 42$ se informa que durante campaña electoral acudió a todos los actos radicales y no está afiliada al Partido Peronista (López, 1952b, foja 2). La tercera observada es docente de la escuela n. ${ }^{\circ}$ 133, afiliada al Partido Peronista Femenino, al que dirigió el día 9 de noviembre un telegrama de renuncia (López, 1952c, foja 3).

En un tercer expediente, también de 1952, el Ministerio de Asuntos Políticos eleva un informe al gobernador de Chubut, con referencia a empleados dependientes del Ministerio de Educación que se consideran no peronistas o no identificados totalmente. Incluye una nómina producida por el Ministerio del Interior, la Gobernación de Chubut, de ocho profesores del Colegio Nacional Trelew y secciones anexas (Martínez, 1952, foja 2bis). Un cuarto expediente se inició a partir de una denuncia realizada por una maestra contra el director de su escuela de la localidad 
Juan Bernarbé Molina, en Santa Fe. El informe es elevado por el gobernador de la provincia al Ministro del Interior (Carcamo, 1952). El informe más amplio de inteligencia sobre docentes se produce en Córdoba, donde se investiga al conjunto de personal docente de varios colegios de la Provincia. El informe es remitido mediante circular secreta por el gobernador de la provincia de Córdoba al ministro del Interior de la nación, con copia al ministro de Educación de la nación y al jefe de la Coordinación de Inteligencia del Estado (CIDE), posteriormente denominado Servicios de Inteligencia del Estado (SIDE). Al mismo tiempo se deja constancia de que la información ha sido transmitida también al ministro de Asuntos Políticos (Lucini, 1952, pp. 1-6).

Un elemento que aparece como definitorio al momento de despedir a un docente investigado es el haber actuado como fiscal de partidos opositores. Entre los papeles secuestrados en el Ministerio de Asuntos Técnicos que fue dirigido por Raúl Mendé se hallaba una carta de un amigo de su localidad natal, Esperanza, pidiendo la restitución de una profesora despedida de la Escuela Normal, a quien defiende como buena persona y profesora. Esta carta se hallaba junto a un memo de fecha anterior en el que Mendé informaba al Ministro de Educación que esa docente fue fiscal de la UCR, y en el que también denunciaba a otra docente del mismo establecimiento por ser contraria al Gobierno. Es decir, se le pidió auxilio a la misma persona que había denunciado a la docente en primer término. Esta es una parte de la respuesta que recibió, posiblemente redactada por Mendé.

Buenos Aires, 28 de marzo de 1952.

Estimado Z., en mi poder tu atenta del 3 del corriente, en la que te refieres al sumario iniciado a la señora $\mathrm{C}$.

Hallazgos

ISSN: 1794-3841 | e-ISSN: 2422-409X | DOI: https://doi.org/10.15332/2422409X 
El mismo se ha iniciado en razón a que la misma ha actuado como fiscal de la Unión Cívica Radical en las últimas elecciones.

Los principios democráticos que sustenta la doctrina del Excmo. Señor Presidente de la Nación, General Perón - estoy seguro que nunca, hasta ahora, en nuestro país se ha gobernado democráticamente- exigen que todo aquel que se desempeña en un cargo público esté identificado con el Gobierno; el General Perón ha sido elegido por una mayoría abrumadora, razón por la cual como presidente de la Nación tiene la obligación de cumplir fielmente el mandato del pueblo. No se debe, pues, admitir obstáculos al cumplimiento de su cometido.

Los vulgarmente llamados 'contreras' son unos de esos obstáculos en la tarea que realiza el general Perón, pues por no estar identificados con el espíritu popular, no pueden hallarse en condiciones de colaborar con el Gobierno en el cumplimiento del ese mandato.

Por una razón elemental de ética, por imperativo de conciencia, quienes no están con Perón, quienes no están con la mayoría del pueblo deben comprender que no pueden permanecer ni un minuto más usurpando una posición que no les corresponde.

Si ellos no lo entienden así nosotros debemos enseñarles el camino: esto es para nosotros una obligación de lealtad para con la gran mayoría de los argentinos. Si no procediéramos así violaríamos las más elementales normas de ética democrática. (“Estimado Z.”, 1952)

\section{Configuración de una división especial para el control sobre el magisterio}

Mario Walter Pereyra, ayudante militar y hombre de extrema confianza del general Uriondo - jefe de la CIDE-, relata un suceso de 1950 que parece ser el origen de una nueva política de inteligencia que se implementaría contra los docentes. Según el relato de Pereyra, la escena tiene lugar a las 21.30 horas de la noche, en forma desusada; Perón permanecía su 
despacho en casa de Gobierno. Ese día le habían exigido la renuncia a Ivanisevich; Méndez San Martín se encontraba junto a Perón, pero todavía no había jurado como ministro. Entonces, Perón llamó al general Uriondo y le pidió "un oficial de informaciones de confianza para 'destruir las mafias y trenzas que existían hace 80 años en Ministerio de Instrucción Pública”. Uriondo regresó a su despacho, hizo algunas consultas, y tras estas aceptó la sugerencia de su ayudante de nombrar a Carlos Alberto Palacios, de quien se pidió el pase desde aeronáutica. Este nombramiento se concretó en 48 horas, y Palacios fue indicado adscrito desde Presidencia en el Ministerio de Educación (Pereyra, 1955, foja 19).

Dos documentos secretos del Ministerio de Educación dan cuenta del trabajo de inteligencia sobre los docentes y las funciones que el personal de la CIDE tenía asignadas. El documento secreto "Plan básico de las informaciones necesarias en el Ministerio de Educación para alcanzar los objetivos establecidos en el II $^{\circ}$ Plan Quinquenal" prueba que el control ideológico sobre los docentes era un objetivo explícito de las autoridades. El plan está dividido entre rama administrativa, docente y cultura. En cuanto a la rama docente, enumera las siguientes informaciones que deben ser recabadas respecto a una serie de ítems (programas de estudio, cuerpo docente, gremios, asociaciones estudiantiles, etc.):

Programas de estudio:

a. Se ajustan los programas, coordinadamente en todas las materias y ramas de la enseñanza, a los objetivos fundamentales que persiguen la doctrina nacional y el Segundo Plan Quinquenal?

b. Cuando así fuere... se aplican esos programas sin deformaciones maliciosas desde la cátedra?

c. Cuáles son los docentes que, tendenciosamente, se apartan de los principios establecidos en los planes de estudios?” 


\section{Cuerpo docente:}

a. Cuál es el personal docente que profesa doctrinas espirituales o políticas adversas a la doctrina nacional y, por ende, a los objetivos del II Plan Quinquenal?

b. Cuál es el personal que sin haberse podido individualizar aun como contrario a aquella doctrina, se desempeña, no obstante, al margen de sus premisas y, por tanto, de los objetivos fijados en el II Plan

Quinquenal?

Gremios:

a. Qué asociaciones gremiales agrupan al personal docente, en todas sus ramas?

b. Quiénes son sus dirigentes y cuál es su posición intelectual, espiritual, moral y política?

c. Qué cuestiones gremiales tienen pendientes? (S. A., s. f.a, p. 2, subrayado en el original).

Un segundo documento muestra la forma como se obtenía esta información. El documento se titula "Servicio de enlace y coordinación". Se trata del reglamento administrativo del servicio de información del Ministerio de Educación. Cabe señalar que el documento por momentos está redactado en tiempo futuro, lo que daría lugar a dudas respecto a si efectivamente este se constituyó. Sin embargo, se cuenta con otros documentos en los que se mencionan las actuaciones de este servicio de enlace. Por ejemplo, a una docente que quería apelar su despido el gremio le informa que debe presentar certificados policiales, los cuales debe gestionar en el servicio de enlace del Ministerio de Educación (S. A., s. f.a, foja 261). En las palabras de esta fuente:

El servicio de enlace y coordinación del Ministerio de Educación, de carácter estrictamente secreto, depende en forma directa de S. Excia. el 
Sr. Ministro de Educación, relacionándose por medio de Coordinación de Informaciones del Estado, con los demás organismos nacionales existentes, a fin de obtener las bases informativas para la mejor ilustración de su Excelencia y demás dependencias del Ministerio que la solicitan. (S. A., s. f.b, p. 1)

La finalidad fundamental del servicio de informaciones era proporcionar al ministro una base informativa integral. El servicio será estrictamente secreto; hará uso de enlaces e informantes. Para la selección de informantes recomienda elegir a aquellos que se proponen por patriotismo y no por mero interés; la persona que selecciona un informante es responsable por este. También plantea que es preferible no reclutar un informante recomendado por otro, para que no se conozcan entre sí y poder cruzar información de distintas fuentes.

El jefe del servicio, por medio de enlaces, recibe los partes secretos o confidenciales de la CIDE y los pasa a la oficina G para la elaboración de partes de "gremiales" o "educación" destinados al Sr. Ministro. También fiscaliza la oficina en la que se hacen aquellos y donde se debe llevar un fichero gremial. La oficina $\mathrm{G}$, a cargo de un dependiente, responde directamente al jefe de servicio I, y recibe los partes confidenciales o secretos de la CIDE. Edita un boletín informativo para el Sr. Ministro; lleva archivos y fichas correspondientes. Por su parte, la Oficina de prensa a cargo del dependiente que responde a jefe de servicio "I" lee en los diarios lo relativo a educación e informa al jefe de servicio.

Bajo el título "Funciones del servicio I" se detallan los datos que este debía procurar, organizados según las distintas ramas. Como se observa, sigue en forma fiel los lineamientos del documento "Plan básico de las informaciones necesarias en el Ministerio de Educación para alcanzar los objetivos establecidos en el II. ${ }^{\circ}$ Plan Quinquenal”, algunos de cuyos fragmentos repite textualmente. Para la rama docente se requiere saber: 
Cuáles son los docentes que tendenciosamente se apartan de los principios establecidos en los planes de estudios.

Si se adjuntan [ajustan] a los programas, coordinadamente en todas las materias y ramas de la enseñanza, a los objetivos fundamentales que persigue el superior Gobierno de la Nación.

Si se aplican esos programas sin desviaciones maliciosas desde la cátedra.

\section{CUERPO DOCENTE}

Cuál es el personal docente que profesa ideologías espirituales o políticas adversas a la doctrina nacional.

Cuál es el personal que, sin haberse podido aún como contrario a dicha doctrina, se desempeña, no obstante, al margen de sus premisas.

\section{GREMIOS}

Qué asociaciones agrupan al personal docente, en todas sus ramas.

Quiénes son sus dirigentes y cuál es su posición intelectual, espiritual, moral y política

Qué cuestiones gremiales tienen pendientes. (S. A., s. f. b, pp. 15 y 16)

Pero no todas las fuentes de información estaban tan profesionalizadas. En otros casos eran militantes del partido que trabajaban en las escuelas quienes cumplían esta función de "observación" dentro y fuera de estas. En el Instituto Politécnico Gral. José de San Martín, posterior escuela fábrica nacional n. ${ }^{\circ} 224$ de Cañada De Gómez, donde la obligación de afiliarse al partido peronista regía para todos los docentes, para los alumnos becados del curso de aviación y para los padres de estos, el mayordomo de la escuela, el señor L., se encargaba de tomar lista en los actos del Partido Peronista y de la CGT. El mismo señor L. llevaba al establecimiento las 
invitaciones a dichos actos que eran comunicadas por circular a los

profesores. L. expresó "que sabía controlar la asistencia de personas a esos actos pero no en cuanto empleados púbicos, sino cuando dichas pertenecían a entidades gremiales" (Gabriel, Pagani y Morán, 1956, p. 4). En la medida en que la asociación gremial o partidaria de los profesores era obligatoria, esta distinción era en realidad superflua.

Otra docente dice que el Partido Peronista cursó en forma simultánea una invitación a un acto doctrinario al personal de la escuela, con un pedido de la nómina del personal. Eso los hizo sospechar que era para tomar asistencia y represalias contra los que no fueran. La docente, que no podía ir, en forma privada consultó al director su parecer, quien no guardó reserva de dicha conversación, ya que dos días después la llama el organizador del acto, diciéndole que su prevención era innecesaria (Gabriel, Pagani y Morán, 1956, p. 8). Esto se explica porque el director de la escuela era el gestor del Partido Peronista en la localidad. El señor L. hacía distintas observaciones a los docentes, como llamarles la atención si no cumplían con el luto por Eva Perón.

Otro caso similar aparece en la provincia de Neuquén. Una mujer que desempeñaba en la escuela $n .{ }^{\circ} 60$ un cargo docente, pese a no tener el título habilitante, presiona a maestras a colaborar con el Partido Peronista Femenino de Plottier. Una de ellas le indica que no puede hacerlo por vivir fuera de la localidad; de hecho, había solicitado traslado a Plaza Huincul donde su marido trabajaba como petrolero. La mujer que ejercía docencia informa al supervisor que esta maestra había hablado mal del Gobierno. Se le inicia un sumario y se le niega el traslado (Verdun de Di Gregorio, 1955, foja 2). 


\section{Las federaciones docentes entre el oficialismo y la oposición}

En un primer momento, el mismo gremio docente pide que los maestros opositores sean separados de sus cargos. La Agremiación del Docente Argentino (ADA) es un sindicato formado por iniciativa oficial. Según múltiples testimonios de docentes que participaron de ese proceso, es el propio ministro de Educación el que sugiere su formación, hecho que tuvo lugar en una asamblea en el Luna Park, el primero de diciembre de 1950. A esta ya se habría llevado una lista única de representantes gremiales, orquestada desde arriba por inspectores y otros funcionarios (Gómez, 1956, p. 1; Chernicharo, 1956, p. 3; Paez, 1956, p. 9).

En las actas de la asamblea ordinaria de la ADA, realizada el 12 de diciembre de 1951, diferentes delegados docentes manifiestan su descontento frente a la permanencia en el cargo de maestros y profesores de orientación política contraria al Gobierno. Por ejemplo, el delegado de Entre Ríos manifiesta que en su provincia "mientras muchos docentes con verdadero espíritu justicialista están demorados han llegado confirmaciones, hasta 24 horas, a personas que no están agremiadas, y que pertenecen al viejo régimen" (Agremiación del Docente Argentino [ADA], 1951, p. 197). El señor Fabiano afirma:

[...] debemos infundir fuego y debemos incendiar a esos viejos compañeros que todavía no quieren entrar, que no quieren entender después de seis años la doctrina justicialista del general Perón (muy bien! Aplausos) Es menester que dejemos las contemplaciones. Hemos esperado seis años, no se puede aguantar más.

[...] Por otros medios he llegado a saber también que en el territorio de Formosa una docente argentina, que ha sido escuchado por esa delegación, ha hecho alarde de radicalismo contra el general Perón, y todavía no se ha tomado ninguna medida.

Hallazgos

ISSN: 1794-3841 | e-ISSN: 2422-409X | DOI: https://doi.org/10.15332/2422409X 
Creo que cuando hay cargos concretos debemos atropellar porque se trata del bien de la patria y de la niñez (APLAUSOS)... (ADA, 1951, pp. 277-278)

Cabe señalar que la trayectoria posterior de la ADA no está exenta de vicisitudes. En mayo de 1953, tres miembros de su comisión directiva fueron sancionados y separados de sus cargos, a lo que se suma la renuncia de otros tres integrantes (ADA, 1953, párr. 1).

$\mathrm{Al}$ año siguiente, la ADA fue intervenida por la CGT, en junio de 1954, y tiempo después se conformó UDA, con características similares a las de su antecesora, de la que hereda los bienes. Primero son designadas autoridades provisorias que luego son ratificadas en una elección organizada en enero de 1955. Al igual que ADA, pese a sus buenos vínculos iniciales con el Gobierno, en particular con el Ministerio de Educación, UDA pronto tiene algunas dificultades. En el centro de estas aparece la pelea por la sanción del Estatuto Docente.

La federación docente escribe un proyecto, pero el Gobierno saca un estatuto por decreto sin consultar al gremio. Esto desata quejas de diversos gremialistas (Zambrano, 1956, p. 284). José Antonio Núñez (1956), presidente del Consejo Directivo de UDA, plantea que "el estatuto promulgado por el gobierno no contó con la adhesión inmediata del Consejo Directivo, quien hizo llegar a Ministerio de Educación sugerencias concretas sobre aquellos puntos que resultaban inconvenientes" (p. 272). Si bien estas afirmaciones son retrospectivas, quedan ratificadas en documentos de la UDA del periodo peronista: UDA no defiende en su totalidad el Estatuto. Por el contrario, en todo momento realiza salvedades. Por ejemplo, en un volante de octubre de 1954 la UDA señalaba al estatuto como una de sus conquistas, pero, al mismo tiempo, cubriéndose de posibles críticas, señala que esta norma legal no es estática, sino que es perfectible: 
Auspició el Estatuto Docente cumpliendo con serena decisión el mandato de la Asamblea. Este elemento legal es hoy una realidad irrefutable. Setenta años esperó el magisterio y el profesorado argentinos la ley orgánica que sancionara sus deberes y defendiera sus derechos.

En siete meses de vida de la UDA, el general Perón implementó el Estatuto que lleva su nombre.

Por vez primera se asegura la estabilidad, el escalafón y la dignidad del educador, dentro de un estado docente. Este decreto es una brecha abierta para futuras conquistas: no es un reglamento estático, sino que es perfectible y de inacabables posibilidades. La UDA ha sabido valorar en toda su histórica significación este gesto de nuestra gran Presidente. (Consejo Directivo Central, UDA, 1954, párr. 6, énfasis añadido)

En un documento de julio de 1955, la entidad reitera:

El episodio más difícil fue la sanción del Estatuto del Docente; el trabajo del gremio trajo como consecuencia la redacción de otro proyecto por parte del Ministerio que luego fue sancionado por decreto. Fue un triunfo de la organización pese a todo lo que se dijo. Naturalmente, como en la elaboración de dicho estatuto no se consultó a la parte gremial el mismo adolecía de fallas que provocó descontento entre la masa de afiliados. Pero, como precedente había sido una conquista incuestionable. Lamentablemente ello trajo serias consecuencias para la C. Directiva, pues las autoridades del Ministerio al parecer no vieron con agrado la acción tenaz de los dirigentes en propiciar y solicitar por todos los medios la sanción de dicho Estatuto, y la entidad pasó por graves momentos. Llegó un instante en que oficialmente llegó a desconocerla, y un acto político apareció auspiciado por “un grupo de maestros” ignorándose al gremio propiciado por las mismas esferas pocos meses atrás. (UDA, 1955a, p. 1) 
De esta manera, la UDA reconoce las limitaciones del Estatuto y la existencia de un malestar entre los asociados. También admite haber recibido dos críticas contrapuestas: la de quienes se quejaban por lo insatisfactorio del Estatuto y la de quienes, en sentido contrario, los acusaban de impolíticos por haber presionado demasiado y por haber enajenado la buena voluntad del Ministerio. Tras enfrentar esta situación, en septiembre-octubre de 1954 decidieron organizar una gira dentro del país para intentar concientizar a los afiliados sobre la diferencia existente entre el Ministerio y la entidad gremial. Gracias a esto "el maestro terminó de convencerse que UDA y el Ministerio de Educación no eran una sola cosa y que cada uno actuaba independientemente" (UDA, 1955a, p. 1). Por supuesto, esta era una tarea difícil, ya que el mismo Ministerio había "propiciado" la creación de la UDA.

\section{El impacto de los despidos}

Los despidos docentes alcanzaron una magnitud preocupante. Según el entonces secretario general de UDA, estos llegarían a 1500 hacia el momento de la caída del régimen (Núñez, 1956, foja 273). También se aplicaron traslados como sanciones punitivas a docentes opositores o acusados de serlo.

Como se ha visto, el gremio docente, ADA, inicialmente reclamaba por la remoción de los docentes opositores. Su sucesora, UDA, hizo efectiva esta demanda al expulsar del gremio al docente y delegado gremial mendocino, por insultar la memoria de la jefa espiritual de la nación, y luego fue despedido por el Gobierno (UDA, Tribunal de Disciplina, 1954, foja 23). Pero, como se observa en los documentos vinculados al servicio de información que actúa en el Ministerio de Educación, no solo se quería docentes peronistas, sino docentes que no criticaran medidas de Gobierno, por ello el Servicio "I" debía identificar y recabar información de "los que 
exteriorizan disconformidad con órdenes emanadas de la superioridad”. Con estos lineamientos, los propios docentes peronistas podían ser víctimas de la depuración justicialista del magisterio.

En este contexto, UDA, sucesora de ADA, comienza a "defender" a los docentes peronistas despedidos. Es evidente que por esta misma contradicción fueron pocos los docentes que solicitaron su auxilio, tan solo alrededor del $10 \%$ de un total aproximado de 1500 despedidos ${ }^{1}$.

Aun así, en forma progresiva UDA va a intentar frenar los despidos, sobre todo cuando se vuelven contra los propios docentes peronistas, afiliados de esa entidad. Según la comisión de investigación, el Tribunal de Disciplina de UDA llevaba 162 expedientes de docentes despedidos. Entre estos no se halló registro de que ninguno se resolviera en forma favorable. El secretario general de la entidad reconoció que los casos que se solucionaron fueron ínfimos (solo se encontró mención a un caso colectivo en Chaco). Otros docentes defienden también el actuar de la UDA, pese a la ausencia de resultados, por la cual responsabilizan a las autoridades del Ministerio (Núñez, 1956, fojas 272-274; Cancedo, 1956, foja 251; De Acosta D’Doll, 1956, foja 303).

De acuerdo con los expedientes que llevaba el sindicato, un reclamo de una maestra de La Pampa no prospera por falta de elementos de juicio. Esto es evidencia de que es el docente quien debe demostrar su inocencia y no al revés. En seis casos el Tribunal argumenta que los docentes no se ajustan al reglamento para encausar su reclamo. En función de los casos en que se vio el conjunto del expediente, lo más probable es que esto signifique que los docentes no brindan los comprobantes de buena conducta peronista

\footnotetext{
${ }^{1}$ La cifra del $10 \%$ figura en los informes de la Comisión y parece una estimación razonable dado que UDA llevaba 162 expedientes sobre una estimación de 1500 cesantías (Comisión Investigadora del Ministerio de Educación. Subcomisión Investigadora de UDA, s.f.a, foja 332; Nuñez, 1956, foja 273).
}

Hallazgos

ISSN: 1794-3841 | e-ISSN: 2422-409X | DOI: https://doi.org/10.15332/2422409X 
que se les solicitan, o que no fundamenten su reclamo en la existencia de un error al considerarlos opositores. A esto se suman un caso en el que el Tribunal se declara incompetente porque la causante (profesora de Tandil) se hacía eco de informaciones periodísticas del lugar y tres casos en los cuales se suspenden las actuaciones debido a que se comprueba que los docentes despedidos tenían vinculaciones con partidos opositores. Por último, el expediente de una maestra correntina despedida en 1947 no avanza porque le solicitan que, para darle curso, es necesario que remita fichas avaladas por el Comando Táctico peronista (Comisión Investigadora del Ministerio de Educación. Subcomisión Investigadora de UDA, s. f.b, fojas 260-270). Es decir, del total de expedientes relevados por la Comisión, doce no prosperan porque o bien el docente no aporta pruebas y argumentos que den cuenta de su filiación peronista o porque se comprueba su adscripción a otros partidos. El Tribunal solo parece dispuesto a defender a los docentes peronistas, pero, aun así, esta filiación partidaria no era garantía de la pronta solidaridad gremial, como se verá en el caso de la docente LZ ${ }^{2}$ (Ioberti, 1956, fojas 296 y 307).

\section{Análisis de tres casos}

El docente IG solicita en 1954 auxilio en la revisión de su cesantía que databa de dos años y medio atrás cuando era secretario de inspección, seccional de escuelas de Corrientes. El docente escribe como peronista (IG, 1954, fojas 39-43). UDA inicia un expediente y nombra un sumariante, quien se dirige a la provincia a recabar información. Para ello se entrevista con los docentes que trabajaron con IG, a quienes pregunta por su

\footnotetext{
${ }^{2}$ Se emplean las iniciales para proteger la identidad de los docentes de quienes se brindan datos sensibles, como sus posiciones políticas o religiosas en consonancia con la reglamentación del Archivo General de la Nación, en el que se ha recabado la documentación citada.
} 
desempeño docente, gremial y político (Artida, 1955, foja 72; Bengoa, 1955, foja 73 ; Córdova, 1955 , foja 74 ).

De forma simultánea, UDA solicita los antecedentes de IG al Ministerio de Educación. Se requiere información sobre la orientación política y profesional (Caporaletti, 1955, foja 78). Le contestan que su labor profesional es adecuada, pero que no pueden abrir juicio sobre su orientación política porque no se le conoce posición ni se lo ha visto en actos fuera de aquellos a los que invitaba el Partido Peronista y la CGT a la gente que trabajaba allí (Inspección General Corrientes, 1954, foja 79). Esto deja entrever que la asistencia a tales actos era considerada obligatoria para el personal del Ministerio.

Se conserva también el informe policial. Este informa que no consta la afiliación de IG al Partido Peronista y que, en cambio, está clasificado en la "Sección orden social y político" como activo militante comunista. Entre sus actividades se indica que organizó reuniones en sus casas con altos dirigentes, mantiene relación con ellos y se supone que es o ha sido colaborador de La hora (Fernandez, s. f., foja 80).

En el segundo caso, AFP corresponde a un exdirectivo de la escuela de maestros normales de Chascomús. El expediente se adelanta de la misma manera que el anterior. En este caso, el sumariante sí le da la razón al docente de quien destaca su efectiva militancia peronista y concluye que la denuncia contra este sería falsa y tendría su origen en rencillas locales. Por ello solicita al Tribunal de Disciplina la reposición en el cargo del docente (De Acosta D’Doll, s. f., foja 255).

Pero el expediente más significativo es el de la docente LZ, profesora de matemáticas de la Escuela Normal de Santa Fe, despedida en marzo de 1953, cuando tenía 16 años de antigüedad. LZ aparece como una docente 
peronista comprometida, aunque no necesariamente obsecuente o acrítica, y esto le traerá problemas.

LZ se dirige por carta a UDA en abril de 1954. Afirma ser peronista y brinda todo tipo de pruebas de su vocación justicialista. Presenta copia de su carné de afiliación al Partido Peronista Femenino, lista las clases especiales que dictó en su escuela asociadas a la difusión de la doctrina peronista y al Segundo Plan Quinquenal, brinda un resumen de la clase y la transcripción de un cuadro sinóptico que los alumnos copiaron en su cuaderno y enumera los actos y las misas peronistas a los que ha concurrido (dice que su asistencia está registrada en libro asistencia de personal). También adjunta copia de los bonos de ayuda a la Fundación Eva Perón y la foto de su jura de la Constitución Justicialista. Luego agrega, también, respuesta de Perón a su carta, preocupándose por su salud. LZ también pone en conocimiento de UDA que, ante sus consultas, le informaron que el expediente que derivó en su despido se originó en una denuncia de que ella habló contra el Gobierno en una reunión familiar y que hizo lo mismo una vez en clase, denuncia que ella considera falsa (LZ, 1954, fojas 88-92).

En la misma carta LZ dice que hace poco le habían confirmado sus horas - es decir, que había titularizado sus cargos docentes hasta entonces provisorios - y que es sabido que ante tal procedimiento se averiguan antecedentes de los docentes por medio de organismos competentes para asegurar su cumplimiento de los requisitos para ocupar cargos en administración nacional, a saber: su compenetración con el Gobierno, de modo que su labor no obstaculice la gestión de este. Por ello considera esta confirmación como otra prueba de su posicionamiento ideológico. Indica que en forma llamativa la denuncia se basa en dos notas enviadas por la misma persona, que firma una como director de la escuela, y otra en su carácter de delegado de la Agremiación del Docente Argentino, a quien le 
atribuye motivos inconfesables. Y dice que antes de que le llegara el despido, mediante una llamada anónima, fue avisada que miembros de ADA estaban disconformes con la regularización de sus horas docentes y que iban a tratar de denunciarla como no peronista. El problema habría sido que ella recibió confirmación directa de sus horas, por escribirle una carta a Eva Perón sin pasar por ADA, que reclamaba para sí esa facultad. Esto desata la discordia con dirigentes que tenían todas las horas disponibles para titularización preasignadas entre amigos para ampliar, de esa manera, su influencia gremial.

El sumariante se entrevista con el gremialista de ADA que inició la denuncia, y este reconoce haber actuado en este sentido:

El CD de la ex ADA, probablemente con acuerdo del PE. Nacional, había dispuesto que las confirmaciones se efectuaran, sin excepción ninguna por vía gremial tomando al efecto los siguientes requisitos: ficha de datos personales, aval político, certificado de afiliación al Partido Peronista y un informe reservado que debía evacuar la Delegación ejecutiva de ADA, de acuerdo con los representantes del gremio de cada escuela. De acuerdo con este último requisito resultaba que la simple afiliación partidaria no era sino una presunción de carácter político a favor del docente. (Manso, 1954, foja 180)

Alega que en el caso de LZ se le dio la confirmación sin pasar por el gremio y afirma que él solo elevó un informe a la ADA, no para pedir el despido, sino para mantener a la dirección informada de la situación. Agrega que este procedimiento no tuvo consecuencias en lo inmediato para la profesora, quien, sin embargo, fue despedida poco después. El testimonio muestra hasta qué punto se exigía la compenetración con la doctrina peronista para el ejercicio de la docente. Igualmente, resulta relevante el hecho de que se considere que la afiliación partidaria es solo una "presunción de carácter político a favor del docente" y, que, por ende, se 
exigieran otros requisitos para probar la pertenencia al peronismo y poder acceder, conservar o titularizar horas.

Por un lado, se afirma que los bonos de la Fundación Eva Perón los remitía el Ministerio de Educación a las escuelas para que fueran colocados entre los profesores; por otra parte, ante el pedido de UDA, la intervención del Partido Peronista de Santa Fe deja constancia de todos los actos peronistas en los que participó LZ (Intervención del Partido Peronista Santa Fe, 1954, foja 159). La pregunta evidente que surge es: cel partido tenía un listado de la asistencia a los distintos actos?

A su vez, UDA solicita a la delegada censista del Partido Peronista Femenino información sobre LZ. UDA requiere el concepto moral y profesional y "cualquier otro antecedente que permita una apreciación profunda de una conducta política de la citada profesora" (Sarubbi, 1954, foja 63). La delegada censista responde con celeridad el número de afiliada y fecha de afiliación (este dato era central porque una fecha tardía se consideraba un indicio de oportunismo y falso peronismo). Asegura también que no consta colaboración de LZ con el partido y que no frecuentaba los actos políticos (Negretti, 1954, foja 63).

El sumariante comienza también a entrevistar a los colegas de LZ. Les pregunta si ella ha llevado o no luto tras la muerte de Eva Perón y otras cuestiones referidas a su posicionamiento político. Un docente dice que ella habla poco de política, pero la considera consecuente con su afiliación, puesto que asistió a todas las clases de un curso sobre el Segundo Plan Quinquenal (Candiotti, 1954, foja 154). Otro profesor dice que ella no milita, pero que por años de observación la considera concordante con el movimiento; agrega que en los últimos años ella ha tenido "fuertes expresiones contra los adulones y simuladores infiltrados en las filas revolucionarias que exageran sus manifestaciones exteriores para disfrazar sus realidades de contrarios oportunistas. Estimo que estas expresiones 
fueron producto de su temperamento emotivo y sincero" (Vigo, 1954, foja 155). Ambos docentes destacan las cualidades morales y profesionales de LZ, quien en todo momento prestaba colaboración con las actividades especiales del establecimiento, incluso fuera de su horario (Candiotti, 1954, foja 154; Vigo, 1954, foja 155).

El sumariante también se entrevista con LZ. En esa ocasión ella reconoce que la discusión familiar a la que alude el expediente de su denuncia existió, pero que ella solo la presenció o formuló alguna crítica constructiva. El sumariante rechaza los argumentos de LZ, ya que aduce que un verdadero peronista no puede presenciar callado cómo se ataca al Gobierno. Tampoco reconoce que las críticas fueran constructivas; considera una falta haber expresado que en la universidad había seudolibertad y que las pensiones estudiantiles estaban más caras que antes. Agrega: "la certificación de afiliación peronista no es prueba concluyente para la calificación ideológica del ciudadano, como lo muestra la experiencia diaria y la exigencia de otros requisitos para el ejercicio de cargos docentes" (Sarubbi, 1955, foja 233). Tampoco considera una prueba válida haber dictado clases especiales sobre el Gobierno o asistido a cursos de formación peronista. A su juicio, estos hechos solo demuestran que es "una docente cumplidora de sus deberes y de las directivas superiores, y por ende su acatamiento a ellos no puede interpretarse como demostración de fe política" (Sarubbi, 1955, foja 233). En la misma tesitura evalúa sus aportes a la Fundación Eva Perón en forma de contribuciones de sueldos y compra de bonos y la jura de la Constitución Justicialista. Destaca que nadie le reconoce una militancia activa en el Partido Peronista y que la "vox populi" la sindica como opositora. Respecto a la participación de LZ en actos peronistas, tanto antes como después de su despido, deja a cargo del tribunal de UDA la estimación de su valor probatorio. Pero de su presentación emerge una valoración 
negativa. En el listado de los actos a los cuales LZ asiste, el sumariante busca distinguir aquellos de participación voluntaria de otros que implícitamente se reconoce no serían espontáneos, pues estarían "auspiciados" por la escuela. De esa manera la nómina incluye una asistencia "voluntaria" a una conferencia sobre justicialismo, pero las misas por Eva Perón serían "auspiciadas" por la Escuela Normal de Santa Fe, la asistencia al curso del Segundo Plan Quinquenal sería "dictado por disposición superior", y así sucesivamente. Con posterioridad a su cesantía, asistió al homenaje del Partido Peronista Masculino ante el aniversario del fallecimiento de Eva Perón, fue alumna del Instituto del Justicialismo y asistió a una misa auspiciada por UDA. Luego, el sumariante enumera los actos donde ella no estuvo o no se pudo confirmar su presencia.

De estos tres casos, solo en el caso AFP directivo de Chascomús el sumariante recomienda la defensa del afiliado. En cambio, tanto en el caso de IG de Corrientes como en el caso LZ de Santa Fe, el sumariante no se pronuncia, aunque los informes tienden a una respuesta negativa.

\section{Un reclamo gremial: despidan a los antiperonistas, pero verifiquen antes...}

En un volante propio, la UDA afirma de sí misma que

[...] asumió con preocupación y responsabilidad la defensa de los colegas sancionados. En algunos casos ya se ha obtenido la medida reparadora y justiciera. El maestro ya no se siente solo y desamparado en las contingencias de su vida. Hoy tiene en el gremio amigos y compañeros que lo escuchan y se afanan por mejorar su suerte. (Consejo Directivo Central UDA, 1954, párr. 12)

Sin embargo, pese a que todos los docentes que cita la comisión investigadora se les pregunta sobre los resultados de las gestiones del 
Tribunal de Disciplina de la UDA, solo hay un testimonio que referencia un resultado positivo concreto. Un docente afirma haber actuado como sumariante en el caso del despido de seis maestras y un director de la localidad de Las Palmas, Chaco, denunciados por la delegada censista local, es decir, la responsable del Partido Peronista Femenino. Señala que en ese caso se logró neutralizar la medida originada por rencillas internas del partido (Millan, 1956, foja 305), y que este dio lugar a una presentación más amplia al Consejo Superior del Partido Peronista en la que se solicitó limitar las facultades de los organismos locales para tomar sanciones, y así evitar que los problemas partidarios internos se resolvieran por la vía punitiva sobre el empleo estatal (UDA, Tribunal de Disciplina, 1955a, p. 279).

Acompaña la nota un listado de nueve casos en los cuales el Tribunal de disciplina considera que se deben a "situaciones internas en el seno del partido". Se trata de ocho despidos y un traslado (UDA, Tribunal de Disciplina, 1955b, p. 280). Dentro de los despidos aparece en el listado el caso AFP de Chascomús. El caso LZ no es incorporado a esta nómina.

Esta resolución es sumamente ilustrativa: el gremio se dirige al Partido Peronista (y no al Ministerio de Educación u otro organismo estatal) para que este restrinja las medidas disciplinarias tomadas en la esfera laboral. Pero este pedido de recorte de las facultades en realidad las reconoce: puesto que no se niega la injerencia del Partido en este ámbito, o su potestad para señalar a los docentes que debían ser despedidos, sino que solo se solicita que esta prerrogativa quede circunscrita a las máximas autoridades partidarias, y no se la reconozca a dirigentes locales de menor jerarquía. Del mismo modo, no se cuestiona que la falta de afiliación y militancia peronista sea una causante de despido, sino que, en ocasiones, por cuestiones personales, se despida a gente que cumplía con esos requisitos de afiliación y militancia. 
Esto nos muestra que el gremio solo da una verdadera batalla por los docentes peronistas despedidos en forma "injusta”, desde la perspectiva de los cánones del régimen. Cabe señalar que, en el pedido amplio, en el que todos los docentes son incorporados, no se solicita la reincorporación de los docentes en forma lisa y llana, sino que se pide - en el marco del estatuto docente-, que se los mantenga en el cargo y que se inicie sumario. Por lo tanto, en estos casos la petición de su defensa es solo una formalidad.

En la verdad, la fuerza del reclamo se pone en las medidas más “injustas" desde la misma óptica peronista. En este caso también se incluyen los despidos producidos a mero pedido de los directivos de un establecimiento. Tales casos dan lugar también a un reclamo específico. El Tribunal de Disciplina aconseja al Consejo Directivo Central que presente una petición por seis docentes dejados sin trabajo por simple resolución de directores (uno de Capital, dos de Santa Fe, uno de Misiones, uno de Salta y uno de Buenos Aires) (UDA, Tribunal de Disciplina, 1955d, fojas 281 y 282).

Por otra parte, el fragmento citado más arriba da cuenta del malestar reinante en el gremio. Se habla incluso de "desazón" frente a los despidos. Si bien hay varias notas de reclamos de fecha de julio de 1955, a lo largo de todo ese año aparecen reiterados reclamos de la UDA relacionados con los despidos. En diferentes volantes la UDA plantea como tarea central la revisión de los despidos (UDA Tribunal de Disciplina, 1955b, foja 285-287) $\mathrm{y}$, junto a estos, de otras medidas punitivas como los traslados (UDA Tribunal de Disciplina, 1955c, fojas 283-284). Es probable que esto se relacione con un incremento de despidos y con un correlativo mayor de malestar docente, aunque el clima político posterior a junio puede haber reforzado la actividad gremial en este sentido. Al mismo tiempo, tanto la consecución de la personería gremial, obtenida el 15 de junio de 1955, 
como el recambio de las autoridades de Ministerio de Educación (posterior a dicho suceso) favorecen una mayor actividad gremial.

Un documento del Consejo Directivo que, por sus referencias al cambio de las autoridades de Ministerio de Educación que se produce el 29 de junio de 1955, debe ser posterior a esa fecha, plantea las acciones que se deben tomar en forma inmediata por el gremio. El documento señala que la entidad fue cauta hasta entonces por no haber conseguido la personería gremial, pero que, con esa cuestión resuelta se "ha cerrado la última brecha en nuestro dispositivo legal. Ha llegado pues el momento de accionar en la consecución de las elevadas y nobles finalidades que inspiraron la creación de nuestra entidad sindical" (Consejo Directivo Central UDA, s. f., foja 298, subrayado en el original). Más abajo manifiesta la "convicción de que las nuevas autoridades del Ministerio de Educación vendrán animadas de patrióticos y sanos propósitos”. Además, destacan el papel del gremio para contribuir "a la pacificación de los espíritus" (Consejo Directivo Central UDA, s. f., foja 298).

Un segundo documento dirigido a los delegados especifica las medidas concretas a las que ha de dirigirse esa acción gremial. En primer lugar, figura la "aplicación integral del estatuto del Docente General Perón y como consecuencia del mismo, substanciación de las causas correspondientes a los docentes declarados cesantes sin previo sumario". Pero lo que parece mostrar un giro en la política sindical más claro es el último punto: "Estudio y solución de los problemas que origina la implantación de la ficha aval”. El sindicato que había aceptado la implementación de estos avales y que los había gestionado ahora planteaba la revisión de la medida. Aun en el clima de pacificación y reconciliación nacional que intentó generar Perón durante algunas semanas tras el fallido golpe de Estado, esta nueva perspectiva de la UDA podía atraerle problemas con el Gobierno. Quizás por ello la misma 
circular "recomienda por razones muy especiales, no dar a publicidad este $\underline{\text { texto, }}$ en la prensa ni comentarlo en reuniones de docentes" (Consejo Directivo Central UDA, 1955, foja 292, subrayado en el original). Ya después del golpe de septiembre de 1955, la UDA en su Boletín vuelve a poner en primer término de su listado de reclamos la aplicación integral del estatuto, es decir, la substanciación de las causas de docentes declarados cesantes sin sumario previo (UDA, 1955b, pp. 3-4).

\section{La construcción de hegemonía}

Usar la educación como medio de propaganda de la doctrina peronista y del culto de Juan Domingo Perón y su esposa requería, necesariamente, una fuerte coacción sobre el cuerpo docente. Es decir, la construcción de hegemonía a partir de prácticas que buscan gestar consenso, como en este caso el empleo de manuales escolares peronistas, requirió el ejercicio simultáneo de coacción. A su vez, el consenso del que goza Perón en sus dos primeras presidencias le permitió en un primer momento ejercer esa coacción en forma más amplia e incontestada. Mientras que los despidos docentes habían tenido un fuerte rechazo durante el gobierno militar de 1943-1945, esto no ocurre durante los primeros años de la presidencia de Perón, fuera de la resistencia inicial del laborismo que pronto es desarticulada. La actitud de los gremialistas de la ADA y luego de la UDA es una muestra de esto. Sin embargo, la UDA modifica de manera gradual su posición inicial a medida que los despidos se tornan más numerosos.

En ese sentido, resulta revelador la existencia y los objetivos del Servicio de Enlace y Coordinación del Ministerio de Educación. Este no solo procuraba información respecto a los docentes opositores, sino también de aquellos que manifestaran alguna disconformidad con órdenes superiores o algún tipo de simpatía con la oposición. De esta manera, las medidas terminan por afectar a aquellos que las habían impulsado en primer 
término. La UDA, en un inicio, solo se preocupa por los despidos cuando expulsaban docentes peronistas. Pero después de junio de 1955 parece prepararse para una acción mayor. En ese contexto, la UDA reconoce los despidos como el principal problema gremial, e incluso cuestiona el sistema de avales políticos por parte del Partido Peronista como requisito para el ingreso a la docencia. Sin embargo, no llega a hacer pública esta posición, solo comunicada a delegados gremiales.

La indagación que aquí se presenta da cuenta de despidos a docentes por razones políticas sin sumario previo, lo que contrasta con las prácticas analizadas por Fiorucci. Los casos que esta autora examina representan solo una porción de los despidos. Fuera de ese marco tramitado dentro de los canales institucionales, existieron otros circuitos con una lógica opuesta a la que ella señala. La intervención de los servicios de inteligencia se contrapone a ese carácter espontáneo que ella adjudica a las denuncias de las que son objeto los integrantes de la comunidad educativa. Como lo muestra el caso de LZ, y en contraposición con las tesis de Fiorucci, tener buen concepto entre colegas o entre la comunidad no era algo que pudiera evitar los despidos. Finalmente, estas decisiones no quedaron en manos de los inspectores. De hecho, la creación de un servicio de enlace de la CIDE en el Ministerio de Educación tenía como finalidad limitar la potestad de los funcionarios de dicho ministerio y proceder a una efectiva depuración de la docencia. No es la voz de los débiles la que mueve este escrutinio y control sobre la docencia, sino los aparatos represivos del Estado, especializados en la recolección de información.

\section{Sobre la autora}

Marina Kabat. Doctora en Filosofía y Letras, grado obtenido en la Facultad de Filosofía y Letras de la Universidad de Buenos Aires, donde también recibió los títulos de profesora y licenciada en Historia. 
Investigadora independiente del Consejo Nacional de Investigaciones

Científicas y Técnicas (Conicet). Desempeña sus funciones en el Instituto Interdisciplinario de Estudios e Investigaciones de América Latina (Indeal). Es también docente de la Universidad de Buenos Aires e investigadora del Centro de Estudios e Investigación en Ciencias Sociales (CEICS). Su campo de interés se vincula con los estudios laborales y la historia de la clase obrera. En el último tiempo se ha dedicado al estudio del peronismo en la Argentina. Sus libros más importantes son: Perónleaks. Una relectura del peronismo en base a sus documentos secretos (2017) y Del taller a la fábrica. Proceso de trabajo, industria y clase obrera en la rama del calzado 1880-1940 (2005).

\section{Referencias}

Alliaud, A. (1993). Los maestros y su historia: orígenes del magisterio argentino. CEAL. Anderson, P. (1981). Las antinomias de Antonio Gramsci. Fontamara.

Ascolani, A. (1999). ¿Apóstoles laicos, burocracia estatal o sindicalistas? Dilemas y prácticas del gremialismo docente en Argentina (1916/1943). Historia de la Educación. Anuario, (2), 87-102.

Barry, C. (2009). Evita Capitana. El partido Peronista Femenino 1949-1959. Eduntref.

Cammarota, A. (2010). El Ministerio de Educación durante el peronismo: ideología, centralización, burocratización y racionalización administrativa (19491955). Revista Historia de la Educación Latinoamerican, 15, 63-92.De Luca, R. y D'Auria, L. (2017). Entre el mito y la realidad. Las transformaciones de las condiciones de trabajo y el impacto en la salud de los docentes entre 1990-2015. E. Sartelli y M. Kabat (Coords.). Mentiras verdaderas. Ideología, nacionalismo y represión en la Argentina. 1916-2015 (pp. 189-218). Editorial de la Facultad de Filosofía y Letras.

Doyon, L. (2006). Perón y los trabajadores: los orígenes del sindicalismo peronista. Siglo XXI Editores.

Fiorucci, F. (2012a). El Campo Escolar bajo el Peronismo 1946-1955. Revista de Historia de la Educación Latinoamericana, 18(14), 139-154. 
Fiorucci, F. (2012b). La denuncia bajo el peronismo: el caso del campo escolar. Documento de trabajo 41 (pp. 1-27). Escuela de Educación, Universidad de San Andrés.

Fiorucci, F. (2013). La denuncia bajo el peronismo: el caso del campo escolar. Latin American Research Review, 1(48), 3-23.

Gindin, J. (2008). Sindicalismo docente en México, Brasil y Argentina: una hipótesis explicativa de su estructuración diferenciada. Revista Mexicana de Investigación Educativa, 13(37), 351-375.

Gvirtz, S. (2005). La politización de los contenidos escolares y la respuesta de los docentes primarios 1949-1955. En R. Rein y R. Sitman (Eds.) El primer peronismo (pp. 37-50). Lumiere.

Kabat, M. (2017) Perónleaks. Una relectura del peronismo en base a sus documentos secretos, 1943-1955. Ediciones RyR.

Leyes, R. (2017). Represión a la izquierda en la provincia argentina de Entre Ríos durante la Revolución de Junio, 1943-1945. Izquierdas, (32), 132-150.

Moyano Llerena, C. (1957). La experiencia de 15 años. Revista Panorama de la Economía Argentina, 3, 4-15.

Nardacchione, G. (2014). Una rara avis en el sindicalismo argentino: los sindicatos docentes (1880-2001). I Encuentro Internacional de Educación, Tandil, 29 al 31 de octubre, https://www.ridaa.unicen.edu.ar/xmlui/bitstream/handle/123456789/57/8521.pd $\mathrm{f}$ ?sequence $=1$

Newland, C. y Cuesta, E. (2017). Peronismo y salarios reales: otra mirada al período 19391956. Investigaciones y Ensayos, 64, 75-98.

Nigro, J. C. (1984). La lucha de los maestros. Confederación de Maestros.

Pettiti, E. (2013). La educación estatal en Argentina durante el peronismo: El caso de la provincia de Buenos Aires (1946-1955). Trabajos y Comunicaciones, (39), 1-25.

Pettiti, E. (2017). Más allá de una escuela peronista políticas públicas y educación en la provincia de Buenos Aires, 1946-1955. Prohistoria.

Perazza, R., y Legarralde, M. (2007). El sindicalismo docente en la Argentina. Fundación Konrad Adenauer.

Hallazgos

ISSN: 1794-3841 | e-ISSN: 2422-409X | DOI: https://doi.org/10.15332/2422409X

Vol. 18 N.o 36| julio-diciembre del 2021 
Plotkin, M. (1995). Mañana es San Perón. Propaganda, rituales políticos y educación en el régimen peronista, 1946-1955. Ariel.

Puiggrós, A. y Bernetti, J. L. (1993). Peronismo: cultura política y educación (1945-1955). Galerna.

Sartelli, E. (1996). Celeste, blanco y rojo. Democracia, nacionalismo y clase obrera en la crisis hegemónica (1912-22). Razón y Revolución, (2), 1-60.

Somoza, M. (2006). Educación y Política en Argentina (1946-1955). Miño y Dávila Editores.

Torre, J. C. (2014). La vieja guardia sindical y Perón: sobre los orígenes del peronismo. Ediciones RyR.

Vázquez, S. (2005). Luchas político educativas: el lugar de los sindicatos docentes. CTERA.

Zanatta, L. (2013). Perón y el mito de la Nación católica: Iglesia y Ejército en los orígenes del peronismo 1943-1946. Eduntref.

\section{Documentos y testimonios}

Agremiación del Docente Argentino. (1951). Libro de actas, AGN, AI. FNRP, comisión 20, caja 3.

Artida, L. (1955). Testimonio recabado por J. Caporaletti el 13 de enero en la ciudad capital de Corrientes. AGN AI, Fondo FNRP, comisión 20, expediente 23965, segundo cuerpo, foja 72.

Bengoa, M. (1955). Testimonio recabado por José Caporaletti (representante UDA) el 13 de enero, Archivo General de la Nación (AGN), AI, Fondo Fiscalía Nacional de Recuperación Patrimonial (FNRP), comisión 20, expediente 23965, segundo cuerpo, foja 73 .

Cancedo, F (1956). Testimonio recabado por la FNRP el 24 de enero, AGN AI, Fondo FNRP, comisión 20, expediente 23965, segundo cuerpo, foja 251.

Candiotti, L. (1954). Comunicación a M. Sarubbi, Santa Fe, 7 de agosto, AGN, AI, Fondo FNRP, comisión 20, expediente 23965, segundo cuerpo, foja 154.

Caporaletti, J. (1955) Al Delegado de la C.G.P. Dr. Fermis Goitia, Corrientes, 10 de enero, AGN AI, Fondo FNRP, comisión 20, expediente 23965, segundo cuerpo, foja 78.

Hallazgos

ISSN: 1794-3841 | e-ISSN: 2422-409X | DOI: https://doi.org/10.15332/2422409X

Vol. 18 N.o 36| julio-diciembre del 2021 
Carcamo, L. (1952). Al Sr. Ministro del Interior, Santa fe, 19 de agosto, AGN AI Fondo Ministerio del Interior, expedientes secretos, confidenciales y reservados (Fondo MI ESCyR), caja 118, expediente 162.

Chernicharo, A. (1956). Testimonio recabado por la FNRP, el 11 enero, AGN AI, Fondo FNRP, comisión 20, expediente 23965, primer cuerpo, foja 3.

Comisión Investigadora del Ministerio de Educación. Subcomisión Investigadora de UDA (s. f.a). Actuaciones del Tribunal de Disciplina, AGN, AI, Fondo FNRP, comisión 20, caja 2, expediente 23965 segundo cuerpo, fojas 332-334.

Comisión Investigadora del Ministerio de Educación. Subcomisión investigadora de UDA. (s. f.b). A la subcomisión de primaria. AGN, AI, Fondo FNRP, comisión 20, caja 2, expediente 23965 segundo cuerpo, fojas 260-270.

Comisionado Investigador del Ministerio del Interior. (1944). Memorándum, al Interventor provincial de Mendoza, AGN. Fondo MI ESCyR, caja 50, expediente 474, 28 de abril.

Consejo Directivo Central UDA. (1954). Qué hizo la UDA, volante, Buenos Aires, octubre. AGN, AI, Fondo FNRP, comisión 20 caja 1.

Consejo Directivo Central UDA. (1955). Objetivos de acción inmediata, Buenos Aires, junio, AGN AI, Fondo FNRP, comisión 20 caja 1, foja 292.

Consejo Directivo Central UDA. (s. f.). UDA Acción inmediata, documento con la leyenda: “Confidencial”, AGN, AI, FNRP, comisión 20, expediente 23965, foja 298.

Córdova, L. M. (1955). Testimonio recabado por José Caporaletti el 13 de enero, AGN, AI, Fondo FNRP, comisión 20, expediente 23965, segundo cuerpo, foja 74.

De Acosta D'Doll, E. (s. f.). Al tribunal de disciplina UDA, AGN, AI, Fondo FNRP, comisión 20, caja 2, expediente 23965, segundo cuerpo, foja 255.

De Acosta D’Doll, E. F. (1956). Testimonio, recabado por la Comisión investigadora del Ministerio de Educación-Subcomisión UDA el 11 de enero. AGN AI, Fondo FNRP, comisión 20, caja 2, expediente 23965, foja 303.

“Estimado Z.” (1952). Carta, 18 de marzo, AGN, AI, Fondo FNRP, comisión 31, expediente $152 \mathrm{n}$. de archivo 111. 
Fernandez, S. (s. f.) Memorándum al Sr. Gobernador de la Provincia, Dr. Raúl Castillo. Asunto: Informar antecedentes. S.L. Documento con sello de la Jefatura de la Policía de Corrientes, expediente. 23695 II cuerpo, foja 80.

Franco, A. (Comisario Inspector Jefe de Comisaría) y Amaro, A. (subcomisario). (1952a). Informe al Sr. Jefe de Policía del Territorio, documento con sello: Ministerio del Interior, Gobernación de Río Negro, Jefatura de Policía, Viedma y leyenda: Reservado confidencial, General Roca, 15 de julio, AGN AI, Fondo MI ESCyR, caja 118, expediente $137 \mathrm{R}$, foja 1 .

Franco, A. y Amaro, A. (1952b). Al Sr. Jefe de Policía del Territorio, General Roca, 15 de julio. AGN AI, Fondo MI, ESCyR, caja 118, expediente 137 R, foja 2.

Franco, A. y Amaro, A. (1952c). Al Sr. Jefe de Policía del Territorio, General Roca 16 de julio, AGN AI, Fondo MI ESCyR, caja 118, expediente 137 R, foja 3.

Gabriel, A., Pagani, F. y Morán, F. (1956). Informe de actuaciones de la Comisión Auxiliar Investigadora del departamento de Iriondo: Santa Fe, ÁGN. AI, Fondo FNRP, Comisiones Provinciales, Santa Fe, caja 1, expediente 588.

Gómez, A. (1956). Testimonio recabado por la FNRP, el 11 de enero, AGN AI, Fondo FNRP, Comisión 20, expediente 23965, primer cuerpo, foja. 1.

IG. (1954). Carta a UDA, 22 de junio. Documentación conservada en AGN, AI, Fondo FNRP, comisión 20, expediente 23965, segundo cuerpo, fojas 39/43.

Inspección Seccional Corrientes (1954). Nota 9. A, 12 de enero, AGN AI, Fondo FNRP, comisión 20, expediente 23965, segundo cuerpo, foja 79.

Intervención del Partido Peronista Santa Fe (1954). A Mario Sarubbi, 5 de agosto, AGN, AI, Fondo FNRP, comisión 20, expediente 23965, segundo cuerpo, foja 159.

Ioberti, P. (1956). Testimonio, recabado por la FNRP los días 11 y 17 de enero, AGN, AI, Fondo FNRP, comisión 20, expediente 23965, segundo cuerpo, foja 297.

López, A. (Jefe de Policía del Territorio) (1952a). Memorándum para el gobernador del Territorio Nacional de Río Negro, Emilio Belenguer, Viedma, 25 de julio. AGN, AI, FMI, Exptes. SCyR Caja 118 expte 138S, foja 1.

López, A. (1952b). Memorándum para el gobernador del Territorio Nacional de Río Negro, Emilio Belenguer, 25 de julio. AGN AI, FMI, Exptes. SCyR, caja 118, expediente $138 \mathrm{~S}$, fojas 2 y 3 .

Hallazgos

ISSN: 1794-3841 | e-ISSN: 2422-409X | DOI: https://doi.org/10.15332/2422409X

Vol. 18 N.o 36| julio-diciembre del 2021 
López, A. (1952c). Memorándum para el gobernador del Territorio Nacional de Río Negro, Emilio Belenguer 25 de julio, AGN AI, Fondo MI ESCyR, caja 118, expediente $138 \mathrm{~S}$, foja 3 .

Lucini, R. (1952). Circular Secreta 5, Córdoba 5 de agosto. AGN, AI, Fondo MI ESCyR, caja 118, expediente 164 .

LZ. (1955). Carta a los señores delegados ejecutivos de la UDA, 20 de abril AGN, AI, Fondo FNRP, comisión 20, expediente 23965, segundo cuerpo, fojas 88-92.

Manso, A. (1954). Testimonio recabado por Sarubbi (representante UDA) el 24 de agosto, AGN, AI, comisión 20, caja 2, expediente 23965 segundo cuerpo, foja 180.

Martínez, M. (T. Coronel subsecretario del Ministerio de Asuntos Públicos de la Nación) (1952). Al Sr. Ministro del Interior, AGN AI, Fondo MI ESCyR, caja 118, expediente 138S, fojas 1-4.

Millan, A. (1956). Testimonio ante la Comisión investigadora del Ministerio de Educación Subcomisión investigadora de UDA, Buenos Aires, 24 de enero, AGN, AI, Fondo FNRP, comisión 20, caja 2, expediente 23965, segundo cuerpo, foja 305.

Negretti, C. (1954). Comunicación a Sarubbi, 5 de agosto AGN, AI, Fondo FNRP, comisión 20, expediente 23965, segundo cuerpo, foja 63.

Nuñez, J. A (1956). Testimonio recabado por la FNRP, el 24 de enero, AGN, AI, Fondo FNRP, comisión 20, caja 2, expediente 23965 fojas 272/274.

Paez, L. (1956). Testimonio recabado por la FNRP, el 11 de enero, AGN AI, Fondo FNRP, comisión 20, expediente 23965, primer cuerpo, AGN, AI, Fondo Fiscalía..., foja 9.

Pereyra, M. W. (1955). Testimonio recabado por la FNRP, 23 de diciembre, AGN, AI, Fondo FNRP, comisión 47, caja 1, archivo 4, foja 19.

Policía de la Provincia de Santa Fe. (1945). Telegrama al Ministro del Interior, A. Tessaire, Rosario, 9 de abril. AGN AI, Fondo MI ESCyR, caja 33, carpeta 440.

S. A. (s. f.a). Plan básico de las informaciones necesarias en el Ministerio de Educación para alcanzar los objetivos establecidos en el $I^{\circ}$ Plan quinquenal. Documento conservado en AGN, AI, Fondo FNRP, comisión 20, caja 2, expediente 108044.

S. A. (s. f.b). Reglamento de Enlace y Coordinación. Documento conservado en AGN, AI, Fondo FNRP, comisión 20, caja 2, expediente 108043.

Hallazgos

ISSN: 1794-3841 | e-ISSN: 2422-409X | DOI: https://doi.org/10.15332/2422409X

Vol. 18 N.o 36| julio-diciembre del 2021 
Sarubbi, M. (1954). Comunicación a la srta. delegada del Partido Peronista Femenino, Carolina Negretti, AGN, AI, Fondo FNRP, comisión 20, expediente 23965, segundo cuerpo, foja 63.

Sarubbi, M. (1955). Comunicación al Honorable tribunal de disciplina UDA, 5 de enero, AGN, AI, Fondo FNRP, comisión 20, expediente 23965, segundo cuerpo, fojas 230235 .

Unión de Docentes Argentinos, Tribunal de Disciplina. (1955a). Dictamen 1o, 15 de julio, AGN, AI, Fondo FNRP, comisión 20, expediente 23965, segundo cuerpo, fojas $285 / 287$.

Unión de Docentes Argentinos, Tribunal de Disciplina. (1955b). Resolución 105, Bs. As., 8 de junio. Documento conservado en AGN, AI, Fondo FNRP, comisión 20, expediente 23965, segundo cuerpo, foja 279.

Unión de Docentes Argentinos, Tribunal de Disciplina. (1954). Dictamen 23, 3 de agosto. copia transcripta en AGN, AI, Fondo FNRP, comisión 20, expediente 23965, segundo cuerpo, foja 277.

Unión de Docentes Argentinos, Tribunal de Disciplina. (1955c). Dictamen 13, 18 de julio. Documento conservado en AGN, AI, Fondo FNRP, comisión 20, expediente 23965, segundo cuerpo, fojas $283 / 284$.

Unión de Docentes Argentinos, Tribunal de Disciplina. (1955d). Dictamen 14, 19 de julio. Documento conservado en AGN, AI, Fondo FNRP, comisión 20, expediente 23965, segundo cuerpo, fojas 281/282.

Unión de Docentes Argentinos. (1955a). Boletín informativo, octubre de 1955, Documento conservado en AGN. Fondo FNRP, comisión 20, caja 1, fojas 3 y 4.

Unión de Docentes Argentinos. (1955b). Reservado. Seis meses de acción gremial. Julio, AGN, AI, Fondo FNRP, comisión 20, caja 1, fojas 293 y 294.

Verdun de Di Gregorio, L. (1955). Testimonio, recabado en Neuquén el 28 de noviembre por la Comisión Provincial Investigadora, de la FNRP, AGN, AI, Fondo FNRP, comisión provincial Neuquén, caja 1, expediente 102573, fojas 2 y 3.

Vigo, S. (1954). Comunicación a Sarubbi, M., 7 de agosto. AGN, AI, Fondo FNRP, comisión 20, expediente 23965, segundo cuerpo, foja 155. 
Zambrano, N. (1956). Testimonio recabado por la FNRP el 11 de enero, AGN, AI, Fondo FNRP, comisión 20, expediente 23965, primer cuerpo, foja 284. 